Far Eastern Entomologist

\begin{tabular}{lll}
\hline Number 425: 21-24 & ISSN 1026-051X (print edition) & February 2021 \\
\hline
\end{tabular}

https://doi.org/10.25221/fee. 425.3

http://zoobank.org/References/AC1FA13A-96CA-433E-97CA-7E1B20ED0FE5

\title{
DESCRIPTION OF A NEW SPECIES OF ORPHINUS MOTSCHULSKY, 1858 (COLEOPTERA: DERMESTIDAE: MEGATOMINAE) FROM IVORY COAST
}

\section{J. Háva ${ }^{1)}$, K. Matsumoto ${ }^{2)}$}

1) Forestry and Game Management Research Institute, Strnady 136, CZ-156 00 Praha 5 - Zbraslav, Czech Republic. E-mail: jh.dermestidae@volny.cz

2) Department of Life Sciences, Natural History Museum, London, SW7 5BD, United Kingdom.E-mail: k.matsumoto@nhm.ac.uk

Summary. A new species Orphinus geiseri sp. n. (Coleoptera: Dermestidae) from Ivory Coast (Mt. Nimba) is described, illustrated and compared with similar species. The new species differs from congeners by the structure of the antennae and male genitalia.

Key words: skin beetles, Dermestidae, taxonomy, new species, the Republic of Côte d'Ivoire, Afrotropical Region.

Дж. Хава, К. Матсумото. Описание нового вида Orphinus Motschulsky, 1858 (Coleoptera: Dermestidae: Megatominae) из Республики Кот-д'Ивуар // Дальневосточный энтомолог. 2021. N 425. С. 21-24.

Резюме. Из Республики Кот-д'Ивуар (г. Нимба) описан новый для науки вид жуковкожеедов Orphinus geiseri sp. n. (Coleoptera: Dermestidae). Новый вид отличается от известных видов рода формой усиков и гениталиями самца.

\section{INTRODUCTION}

The family Dermestidae (Coleoptera: Bostrichoidea) recently includes 1705 valid species and subspecies worldwide (Háva, 2018, 2020a). The dermestid genus Orphinus Motschulsky, 1858 belonging to the subfamily Megatominae, recently includes 133 species worldwide and 23 species are known from the Afrotropical Region, all belonging to the nominotypical subgenus (Háva, 2016, 2020b; Kadej \& Háva, 2016). A new species is described here from the Republic of Côte d'Ivoire (Mt. Nimba).

\section{MATERIAL AND METHODS}

The specimen used in this study is housed in the collection of the Natural History Museum, London. The specimens were examined by relaxing in warm water, dissecting the abdomen and its inner contents. Genitalia are placed in a drop of dimethyl hydantoin formaldehyde (DMHF) resin and mounted on a card pinned under the specimen. Habitus photographs were taken with a Canon DSLR camera, Laowa $25 \mathrm{~mm}$ macro lens. All photographs were processed 
through focus stacking software, Helicon Focus and were later edited using GIMP. The beginning and end of label text are indicated using double quotes ("'); a double slash (//) separates the data on different labels.

The following acronyms of morphological characters were used: BL - body length (pronotum length and elytral length), EL - elytral length, EW - maximum elytral width, PL pronotal length, PW - maximum pronotal width.

Type material is deposited in the Natural History Museum (formerly British Museum, Natural History), London, United Kingdom (BMNH).

\section{TAXONOMY}

Orphinus (Orphinus) geiseri Háva et Matsumoto, sp. n.

http://zoobank.org/NomenclaturalActs/4798CBD3-4434-44EA-905F-33608DE1A5E9

Figs 1-5

TYPE MATERIAL. Holotype - male, deposited at BMNH: "Ivory Coast, $801 \mathrm{~m}, \mathrm{Mt}$ Nimba camp, Closed forest, 07³5'07.7"N, 08²5'08.6"W, 28.IV-8.V 2016, // General collecting, Aristophanous,M., Geiser,M., Moretto,P., leg., BMNH(E) 2016-109, TripRef: CI003 (ANHRT 17) // NHMUK13800094". Additional label on red paper added: "Orphinus (Orphinus) geiseri sp. nov. Háva \& Matsumoto det. 2020, HOLOTYPE ${ }^{\lambda} "$.

DESCRIPTION. Male. Body: Oval, dorsum convex. BL: $2.10 \mathrm{~mm}$, EL: $1.49 \mathrm{~mm}$, EW: $1.31 \mathrm{~mm}$, PL: $0.52 \mathrm{~mm}, \mathrm{PW}: 1.14 \mathrm{~mm}$. Colour: dorsal side brown; brown, tibia light brown, tarsal claws light brown.

Body dark brown on dorsal surfaces (Fig. 1), dark brown on ventral surfaces; small and oval (Fig. 2). Head finely punctate, with short, recumbent, light brown setation. Palpi brown; setation on mentum denser. Eye very large, with brown microsetae. Ocellus on front present. Antennae light brown with brown setae, with 11 antennomeres, antennal club consist with two antennomeres, terminal antennomere large, circular (Fig. 4). Antennal fossa circular. Pronotum on the disc punctate like head, relatively consistent density of punctures, with relatively long, recumbent, yellowish-brown setation. Scutellum subtriangular, anterior end concave, without setation. Elytra finely punctate, with relatively long, recumbent, yellowishbrown setation; cuticle dark brown throughout (Fig. 1). Legs brown, with light brown setation. Mesosternum coarsely punctate laterally, otherwise finely punctate, covered with light brown, short, recumbent setation (Fig. 2). Abdominal visible ventrites finely punctate, with relatively long, recumbent, light brown setation (Fig. 3).

Genitalia (Fig. 5). Parameres: longer than median lobe, width relatively constant from base to anterior $1 / 3$, narrowing and curved towards middle from anterior $1 / 3$ to apical end, apex pointed. Median lobe: widest at base, constant width near base towards apex, apical end slightly rounded. Phallobase: nearly symmetrical, trapezial.

Female. Unknown.

DISTRIBUTION. West Africa: the Republic of Côte d'Ivoire.

DIFFERENTIAL DIAGNOSIS. The new species belongs to the nominotypical subgenus due to the structure of the terminal antennomere; from other known Orphinus species, it differs by its characteristic elytral colour; from other species known from Côte d'Ivoire it differs by the characters given in the key below.

ETYMOLOGY. The epithet is a patronym honouring Michael Geiser (BMNH) who collected this species. 


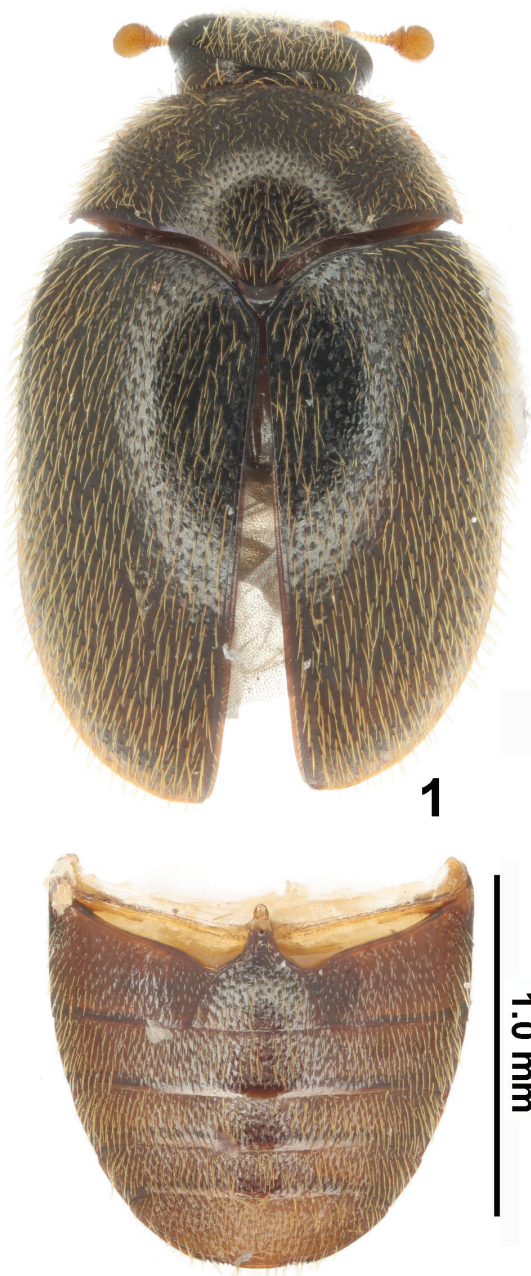

3
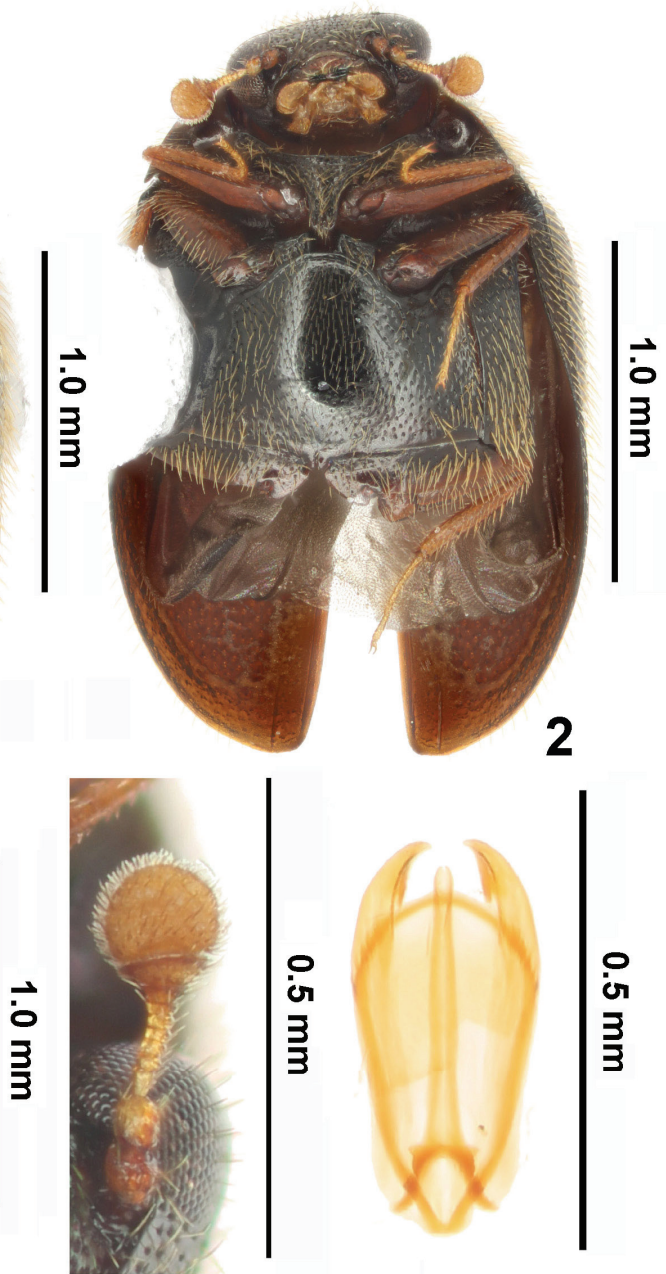

4

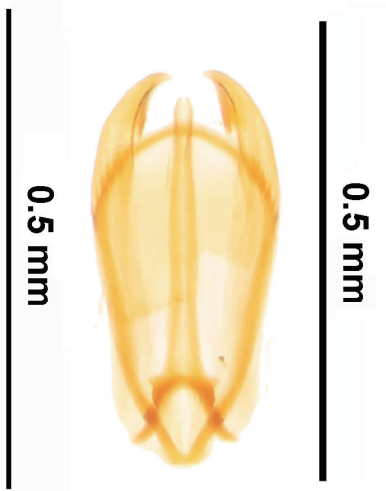

5

Figs 1-5. Orphinus geiseri sp. n., male. 1 - habitus, dorsal view; 2 - the same, ventral view; 3 - abdomen; 4 - right antennae; 5 - genitalia, ventral view.

\section{Key to species of Orphinus from the Republic of Côte d'Ivoire}

1(4) Elytra unicoloured brown without fasciae or spots.

2(3) Elytra and pronotum covered by dark brown or black setation; male anterior pronotal angles visible from above O. congoanus Pic, 1950

3(2) Elytra and pronotum covered by yellowish-brown setation; male anterior pronotal angles not visible from above O. geiseri Háva et Matsumoto, sp. n. 
4(1) Elytra bicolorous.

5(6) Elytra black with orange-brown apical third .................. O. apicebrunneus Háva, 2003

6(5) Elytra dark brown with light brown suture in the posterior $1 / 3$... O. holusai Háva, 2016

\section{ACKNOWLEDGEMENTS}

The sampling and study of material from Côte d'Ivoire was made possible thanks to the support of the African Natural History Research Trust (Leominster, UK) and Richard E.L. Smith. Scientific research in Côte d'Ivoire was authorised by the Ministère de l'Enseignement Supérieur et de la Recherche Scientifique. The Office Ivoirien des Parcs et Réserves (OIPR) is thanked for authorising access and sampling of specimens in Mt Nimba Strict Nature Reserve (Réserve Naturelle Intégrale) under permit no. 216/MINEDD/OIPR/DG, and exportation of specimens under permit no. 308/MINEDD/OIPR/DG. The paper was supported by the Ministry of Agriculture of the Czech Republic, institutional support MZE-RO0118. We would like to express thanks to Max Barclay (BMNH), and anonymous reviewers, for comments on the manuscript.

\section{REFERENCES}

Háva, J. 2015. World Catalogue of Insects. Volume 13. Dermestidae (Coleoptera). Brill, Leiden/Boston. xxvi +419 pp.

Háva, J. 2016. Description of a new Orphinus Motschulsky, 1858 from Ghana (Coleoptera: Dermestidae: Megatominae). Arquivos Entomolóxicos, 15: 265-267.

Háva, J. 2018. A new Orphinus species from Nepal (Dermestidae: Megatominae). Acta Biologica Universitatis Daugavpiliensis, 18(2): 199-201.

Háva, J. 2020a. Dermestidae World (Coleoptera). World Wide Web electronic publication, version 2018, update January 2020. Available from: http://www.dermestidae.wz.cz

Háva, J. 2020b. Study of the genus Orphinus Motschulsky, 1858. Part 1 - descriptions of six new species and neotype designation from the Afrotropical Region (Coleoptera: Dermestidae: Megatominae). Folia Heyrovskyana, Series A, 28(2): 8-17.

Kadej, M. \& Háva, J. 2016. A new species of Orphinus Motschulsky, 1858 (Coleoptera: Dermestidae) from Tanzania. African Entomology, 24(2): 432-436. DOI: https://doi.org/ 10.4001/003.024.0432

(C) Far Eastern entomologist (Far East. entomol.) Journal published since October 1994.

Editor-in-Chief: S.Yu. Storozhenko

Editorial Board: A.S. Lelej, S.A. Belokobylskij, M.G. Ponomarenko, V.A. Mutin, E.A. Beljaev, E.A. Makarchenko, A.V. Gorochov, T.M. Tiunova, M.Yu. Proshchalykin, S.A. Shabalin, V.M. Loktionoy

Address: Federal Scientific Center of the East Asia Terrestrial Biodiversity (former Institute of Biology and Soil Science), Far East Branch of the Russian Academy of Sciences, 690022, Vladivostok-22, Russia.

E-mail: storozhenko@biosoil.ruweb-site: http://www.biosoil.ru/fee 